\title{
Half a century of the reverse transcriptase-happy birthday!
}

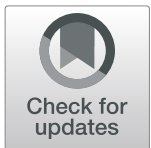

Karin Moelling ${ }^{1,2}$

Correspondence: moelling@molgen. mpg.de

${ }^{1}$ Institute of Medical Microbiology, University of Zurich, 8006 Zürich, Switzerland

${ }^{2}$ Max Planck-Institute of Molecular Genetics, 14195 Berlin, Germany

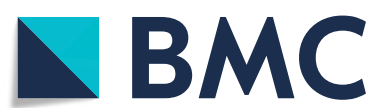

(c) The Author(s). 2021 Open Access This article is licensed under a Creative Commons Attribution 4.0 International License, which permits use, sharing, adaptation, distribution and reproduction in any medium or format, as long as you give appropriate credit to the original author(s) and the source, provide a link to the Creative Commons licence, and indicate if changes were made. The images or other third party material in this article are included in the article's Creative Commons licence, unless indicated otherwise in a credit line to the material. If material is not included in the article's Creative Commons licence and your intended use is not permitted by statutory regulation or exceeds the permitted use, you will need to obtain permission directly from the copyright holder. To view a copy of this licence, visit http://creativecommons.org/licenses/by/4.0/. The Creative Commons Public Domain Dedication waiver (http://creativecommons.org/publicdomain/zero/1.0/) applies to the data made available in this article, unless otherwise stated in a credit line to the data. 


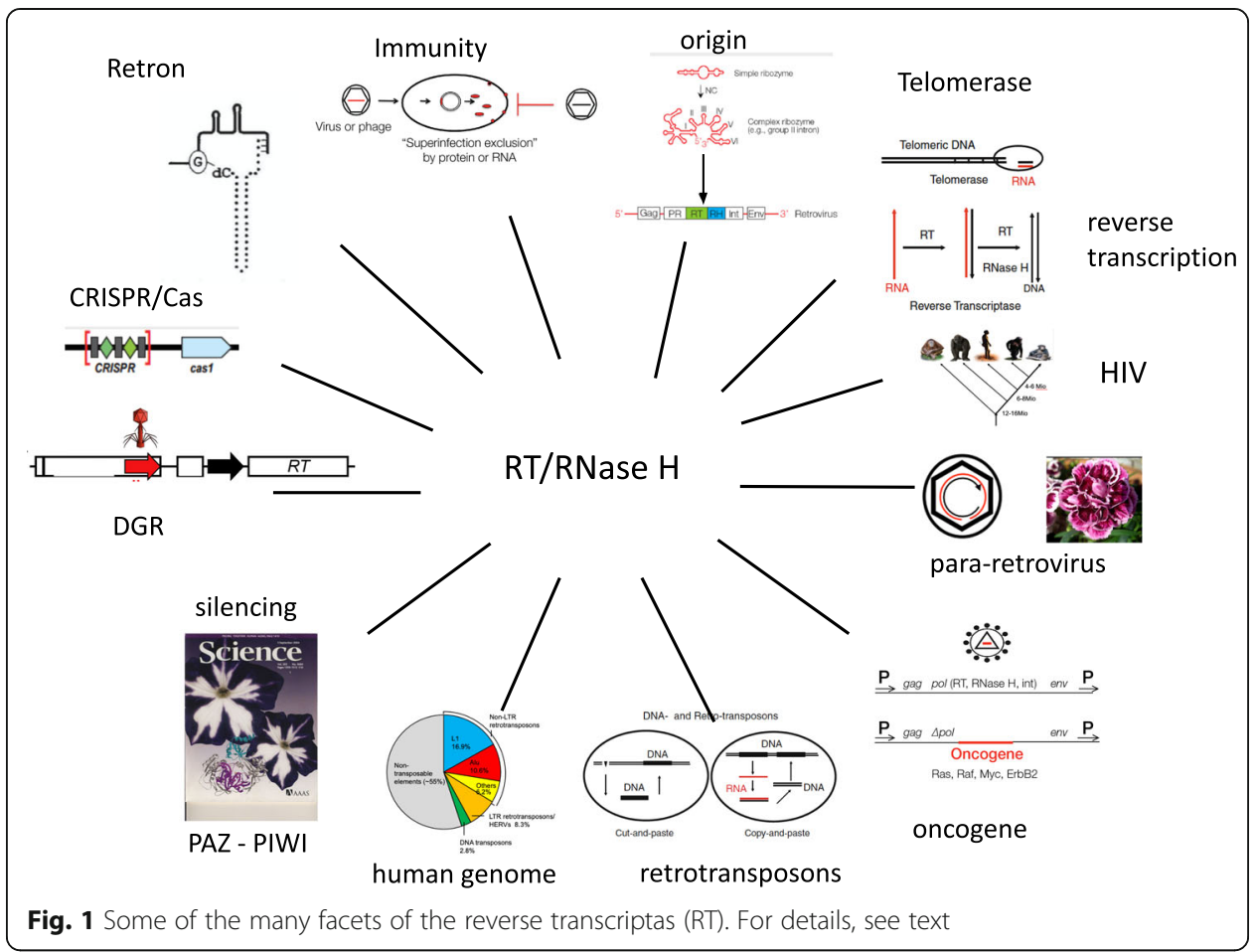

in 1983, and replicates via the RT-and again, the RT is the basis for diagnostics and was the first target of a drug, AZT, in 1987.

RNA tumor viruses can carry oncogenes or activate downstream cellular genes by the viral promotors, the long terminal repeats (LTRs), by promoter insertion. The myc gene plays a role in both of the two mechanisms, causing an acute or chronic disease in animals [6], and is now being explored as a drug target in human cancer. The first prominent tumor retrovirus was the Rous sarcoma virus, RSV, which can replicate and carry an oncogene v-src. The question was the following: are oncogenes from outside of a cell or from within? A Nature preprint from Mike Bishop and coworkers in San Francisco was going around in 1971 or so at the Max Planck Institute of Virology in Tübingen, describing an "oncogene" present everywhere, even in elephants-with no correlation to cancer. The answer to this puzzle was that the oncogene looked the same as cellular genes, the "protooncogenes", with the technologies available. But it was mutated in cancer, not identical. Mike Bishop and Harold Varmus received the Noble Prize for their discovery of oncogenes in 1989.

Harold Varmus attended European Tumor Virus Meetings on oncogenes by riding his bicycle from London across half of Europe even in heavy rain, a pioneer not only in cancer research but for bicycle riding 50 years before this becomes a need now by fear of SARS-coronavirus-2 infections in public transportations.

Many years back, around the 1970s, a slide was projected during one of the CSH meetings showing a healthy chicken which harbored an endogenous retrovirus. This was a surprise, because everybody was expecting a sick chicken, but this one looked perfectly normal. Endogenous viruses were also found in mice and were later identified as endogenous viruses in many species. This culminated in the publication of the most spectacular paper involving retroviruses-the human genome sequence by Eric Lander 
and numerous other authors and groups [7]. This revealed that retroviruses and retrovirus-like elements populate the human and other mammalian genomes to almost $50 \%$ even today, and in some genomes up to $80 \%$ [8]. This was proved by the isolation of "Phoenix," a retrovirus reconstructed from the human genome from a dozen mutated sequences, which allowed the deduction of a consensus ancestral sequence. A DNA copy, transfected into tissue culture cells, produced the replicating retrovirus Phoenix, detectable by electron microscopy. After 5 million years of dormancy, the virus was brought back to "life" [9]. We harbor sequences of the virus Phoenix in our genome from former infections, but nobody seemed to worry about its recent resurrection in the laboratory as a potential danger!

A retrovirus contributed important novel information for the benefit of human evolution: preventing mothers from immune rejection of their own developing embryos. Egg shells and kangaroo pouches became obsolete by a piece of DNA coding for a region of the envelope protein of an ancestor of the human endogenous retrovirus, HERV-W [10]. The mechanism is closely related to immune suppression by AIDS and based on a peptide sequence also found in the gp41 fusion protein of HIV. Cells in the placenta of ancestors of humans and several other female mammals were infected independently 25 to 40 million years ago.

Endogenous viruses can protect against exogenous viruses. This immunity was shown in a real-time endogenization process observed with koalas in Australia. They were threatened by factors such as car accidents or fires and were put into custody to allow the population to recover on an island. It was not as safe a place as expected, because the Gibbon ape leukemia virus habited there and killed many of the koalas. Some of them survived and were immune because the virus had entered their germlines. This allowed scientists to watch such an evolutionary event of endogenization in real time [11]. Endogenization in the koalas took 100 years, about 10 generations. How long will HIV need to endogenize into human germ cell genomes and defend their offspring against superinfection? Infection seems possible and thus endogenization also? Ten koala generations may correspond to 250 years for humans-this is too long to wait for!

This protection by endogenous viruses against exogenous viruses is not dissimilar to one approach bacteria have evolved as defense against phages. A DNA fragment of an invading bacterial virus/phage is stored as memory, as a "spacer" within palindromic sequences. Its RNA transcript recognizes the DNA genome of an invading new phage by sequence homology and leads to its destruction by molecular scissors, the CRISPR/Cas effect [12], which everyone is aware won the Noble Prize for chemistry this year.

Bacteria harbor many RTs from retroelements. One of these RTs is highly mutagenic and drives evolution by promoting hypervariation of protein sequences, a property shared with the adaptive immune response. This leads to an expanded tropism of bacterial and phage interaction, possibly to adapt to environmental stress. The sequences carrying this RT are called DGR, diversity-generating retroelements [13]. They may help to create broad-spectrum phages. Another puzzling RT in bacteria belongs to retrons, which consist of branched single-stranded RNA/DNA structures [14] which Howard Temin had already noticed [15]. It looks like a conserved evolutionary intermediate from RNA to DNA. Bacterial RTs can also bind to catalytic RNAs (group II introns) [16]. They also resemble transition intermediates from the RNA to the DNA world with the RT as link between the two worlds [17] making the RT a major driver in evolution. 
There is another relative of the RT. Also connected to the CSH Laboratory is TERT, the telomeric RT, described by Elizabeth Blackburn and Carol Greider, frequent guests at CSH, who received the Nobel prize together with Jack Szostak in 2009. TERT elongates chromosomal ends in embryonic tissue and stem cells and is active in cancer cells corresponding to longevity [18]. Unlike other RTs, an RNase H is not involved, since RNA is needed as a template for the repeated copies of the telomeric DNA. Linear chromosomes need protection of their ends against shortening which is provided by TERT and its stable pseudoknot RNA structure. TERT has been proposed to be related to non-LTR retrotransposons, which lost an endonuclease [19]. Is this the oldest ancestral RT precursor, a ribonucleoprotein consisting of non-coding pseudoknot-structured RNA and the RT enzyme or are introns the origin?

Last not least we give our adoration to Barbara McClintock for her discovery of mobile genetic elements, which include retrotransposons with their copy-and-paste mechanism. Her legacy will continue to keep researchers busy studying this prominent force of genomic evolution and adaptive processes and contribute to many more CSH meetings to come.

This remembrance has shown how broad the RTs are in nature and during evolution and how many open questions still wait for further analysis.

A bunch of flowers makes a nice birthday surprise, so at the end of this overview, we discuss two phenomena visible in plants, related to RT. The first is the white pattern of petunias, which is caused by silencing of the gene responsible for the blue coloring. The silencing depends on the PAZ and PIWI domains of Argonaute proteins which are structurally related to the retroviral RT and RNase $\mathrm{H}$ enzymes. They are components of the RNA-induced silencing complex RISC, which is believed to have evolved as an antiviral immune defense. In contrast, the white rims around carnation petals are

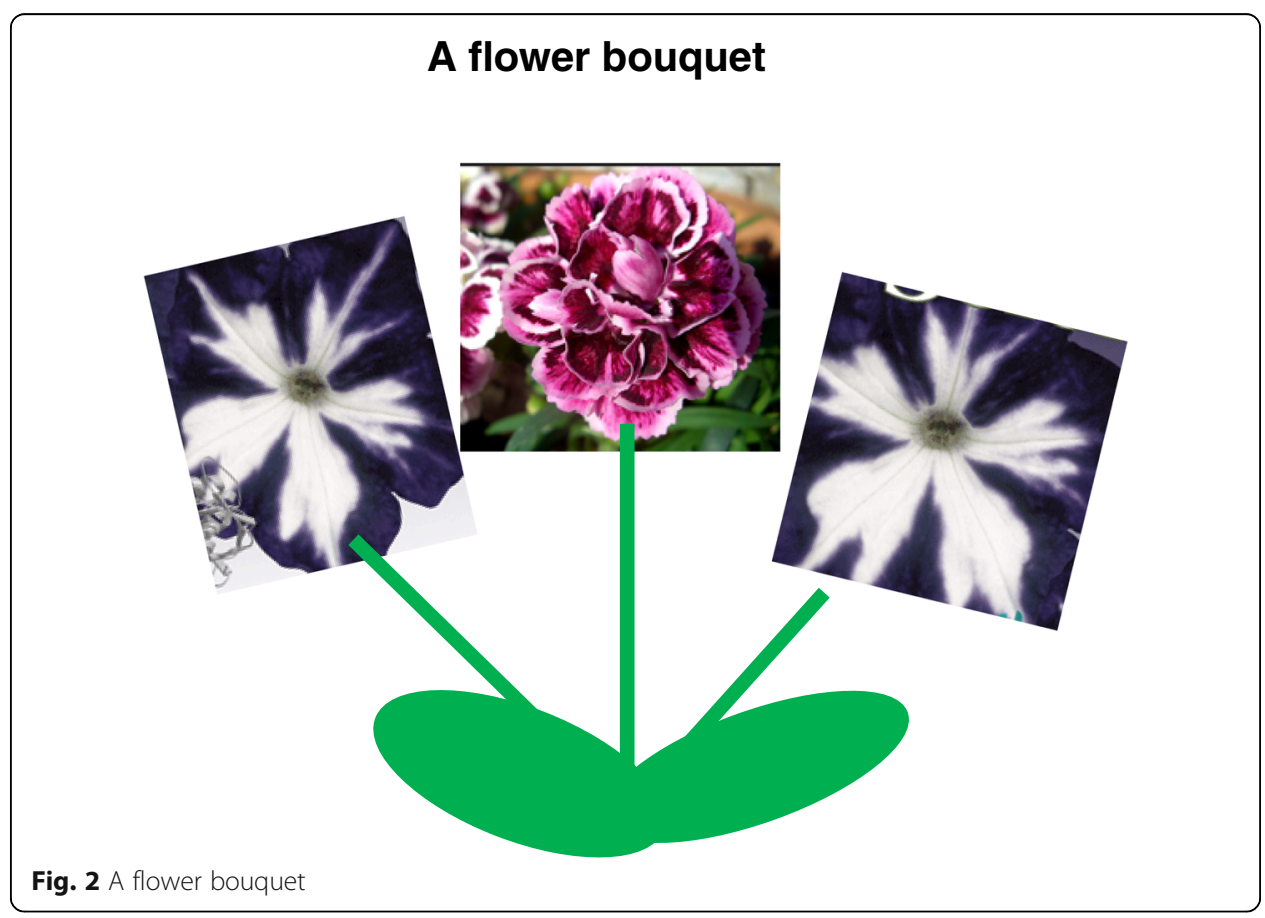


caused by viruses, whereby one of them is the viroid of carnations, CarSVd (Carnation Small Viroid), and the other one a plant pararetrovirus. Its RT helps to make a homologous DNA from the viroid, allowing DNA recombination [20]. Thus, this viroid exploits an RT, presumably provided in trans by a plant pararetrovirus, such as cauliflower mosaic virus leading to color patterns.

A flower bouquet with silenced petunias and multicolored carnations is a greeting for the birthday of the RT, whereby the beauty of flowers is due to RTs (Fig. 2).

Congratulations to David Baltimore and a remembrance to Howard Temin.

Author's contributions

KM wrote the editorial and read and approved the final manuscript.

Competing interests

The author declares no competing interest.

Received: 22 September 2020 Accepted: 4 December 2020

Published online: 11 January 2021

References

1. Temin HM, Mizutani S. RNA-dependent DNA polymerase in virions of Rous sarcoma virus. Nature. 1970;226:1211-3. https://doi.org/10.1038/2261211a0

2. Baltimore D. RNA-dependent DNA polymerase in virions of RNA tumour viruses. Nature. 1970;226:1209-11. https://doi. org/10.1038/2261209a0.

3. Crick FH. The origin of the genetic code. J Mol Biol. 1968;38:367-79. https://doi.org/10.1016/0022-2836(68)90392-6.

4. Barre-Sinoussi F, Chermann JC, Rey F, Nugeyre MT, Chamaret S, Gruest J, et al. Isolation of a T-lymphotropic retrovirus from a patient at risk for AIDS. Science. 1983;220:868-71. https://doi.org/10.1126/science.6189183.

5. Poiesz BJ, Ruscetti FW, Gazdar AF, Bunn PA, Minna JD, Gallo RC. Detection and isolation of type C retrovirus particles from fresh and cultured lymphocytes of a patient with cutaneous T-cell lymphoma. Proc Natl Acad Sci U S A. 1980;77: 7415-9. https://doi.org/10.1073/pnas.77.12.7415.

6. Flint JS, Enquist LW, Racaniello VR, Rall GF, Skalka AM. Principles of virology. 4th Edition American Society of Microbiology (ASM). Washington DC: ASM Press; 2015.

7. Lander ES, Linton LM, Birren B, Nusbaum C, Zody MC, Baldwin J, et al. Initial sequencing and analysis of the human genome. Nature. 2001:409:860-921. https://doi.org/10.1038/35057062

8. Moelling K, Broecker F, Russo G, Sunagawa S. RNase $\mathrm{H}$ as gene modifier, driver of evolution and antiviral defense. Front Microbiol. 2017:8:1745. https://doi.org/10.3389/fmicb.2017.01745.

9. Dewannieux M, Heidmann T. Endogenous retroviruses: acquisition, amplification and taming of genome invaders. Curr Opin Virol. 2013;3:646-56. https://doi.org/10.1016/j.coviro.2013.08.005.

10. Mi S, Lee $X$, Veldman GM, Finnerty $H$, Racie L, et al. Syncytin is a captive retroviral envelope protein involved in human placental morphogenesis. Nature. 2000;403:785-9. https://doi.org/10.1038/35001608.

11. Tarlinton RE, Meers J, Young PR. Retroviral invasion of the koala genome. Nature. 2006;442:79-81.

12. Charpentier E, Doudna JA. Biotechnology: rewriting a genome. Nature. 2013:495:50-1. https://doi.org/10.1038/495050a.

13. Miller JL, Le Coq J, Hodes A, Barbalat R, Miller JF, Ghosh P. Selective ligand recognition by a diversity-generating retroelement variable protein. Plos Biol. 2008;6:e131.

14. Inouye K, Tanimoto S, Kamimoto M, Shimamoto T, Shimamoto T. Two novel retron elements are replaced with retronVc95 in Vibrio cholerae. Microbiol Immunol. 2011;55:510-3. https://doi.org/10.1111/j.1348-0421.2011.00342.x.

15. Termin HM. Retrons in bacteria. Nature. 1989;339:254-5.

16. Simon DM, Zimmerly S. A diversity of uncharacterized reverse transcriptases in bacteria. Nucleic Acids Res. 2008;36: 7219-29. https://doi.org/10.1093/nar/gkn867.

17. Koonin EV, Dolja W. Virus world as an evolutionary network of viruses and capsidless selfish elements. Microbiol Mol Biol Rev. 2014;78:278-303. https://doi.org/10.1128/MMBR.00049-13.

18. Greider CW, Blackburn EH. Identification of a specific telomere terminal tranferase activity in Terahymena extracts. Cell. 1985:43:405-9.

19. Podlevsky JD, Chen JJ-L. Evolutionary perspectives of telomerase ENA structure and function. RNA Biol. 2016:13:720-32.

20. Hegedus K, Palkovics L, Tóth EK, Dallmann G, Balázs E. The DNA form of a retroviroid-like element characterized in cultivated carnation species. J Gen Virol. 2001:82(Pt 3):687-91.

\section{Publisher's Note}

Springer Nature remains neutral with regard to jurisdictional claims in published maps and institutional affiliations. 